\title{
Do Ipês à Polícia - obra de Rubem Fonseca durante a redemocratização
}

From Ipês do The Police - the books by Rubem Fonseca during redemocratization

\section{Ricardo Lísias}

Doutor em Literatura Brasileira Pós-doutorando na Universidade Federal de São Paulo rlisias@yahoo.com.br

Resumo: Sociólogos que se debruçaram sobre o período final da última ditadura militar, conhecido como redemocratização, observaram que a narrativa da "violência urbana" começou a aparecer com cada vez mais força no discurso político da população. $\mathrm{O}$ medo do terrorismo, incutido pelos ideólogos do regime militar, estava sendo substituído por outro, o receio de que a bandidagem se tornava cada vez mais ameaçadora. Alguns ficcionistas colaboraram para o crescimento e a fixação desse novo medo. Esse ensaio procura apresentar o papel nessa transformação de um dos principais autores do período: Rubem Fonseca.

Palavras-chave: ditadura, redemocratização, violência urbana, ficção, Rubem Fonseca.

\begin{abstract}
Sociologists who studied the final period of the last military dictatorship, known as redemocratization, observed that the narrative of "urban violence" began to appear with increasing force in the political discourse of the population. The fear of terrorism, instilled by ideologues of the military regime, was being replaced by another, the fear that banditry was increasingly threatening. Some authors of fiction collaborated to create this new fear. This essay presents the role in this transformation of one of the main authors in the period: Rubem Fonseca.
\end{abstract}

Keywords: dictatorship, redemocratization, urban violence, fiction, Rubem Fonseca. 
Em dezembro de 1987, dez meses antes da promulgação da Constituição que iria, ao menos oficialmente, deixar para trás a da ditadura, promulgada em 1967, Antonio Flavio Pierucci, em ensaio que se tornou uma referência para a sociologia e antropologia brasileiras, percebeu que a "violência criminal" havia tomado conta do imaginário urbano. Se durante o regime militar as pessoas eram orientadas a temer os movimentos de resistência ao golpe, a partir da transição outro grupo deveria agora aparecer nos pesadelos da família brasileira: os criminosos.

Pierucci nota que essa narrativa sempre acompanhava os fatos, reforçando-os, dando-lhes verossimilhança e, inclusive, tornando-os uniformes e coerentes entre si:

O sentimento geral de insegurança, que é autofágico, vem produzindo em certas camadas sociais o surgimento de discursos sobre os males do mundo que brotam, de uma lógica absolutamente protofascista, por um lado, e por outro ancorados nos fatos. São os fatos, experimentados ou narrados, que dizem que a insegurança aumenta, é crescente, não para de se concretizar em mais um fato a cada momento. A experiência da violência criminal é inseparável da experiência da narrativa dos fatos de violência. Há uma espécie de jogo entre discursos e práticas, entre os fatos e suas narrativas sucessivas, no qual um lado confirma o outro, generalizando o medo para todos os pontos da cidade e todos os lugares do social (PIERUCCI, 1987: 32).

Se antes o que tomava conta das conversas de esquina, manchetes de jornal, notícias de TV e outros discursos sociais era o medo dos comunistas, nos anos 1980 o cidadão se sentia ameaçado "pelos delinquentes e criminosos, pelas crianças abandonadas, pelos migrantes mais recentes (...)" (PIERUCCI, 1987: 32). Para os "atentados" saírem de cena, algo precisaria ocupar seu espaço. O assalto fez, com bastante sucesso, esse papel. Com esse objetivo, foi preciso alterar, mesmo que apenas formalmente, as instituições relacionadas à segurança pública.

Governador biônico de São Paulo entre março de 1982 e maio de 1983, José Maria Marin, hoje preso nos Estados Unidos por corrupção durante sua gestão na Confederação Brasileira de Futebol, extinguiu oficialmente o DEOPS (Delegacia de Ordem Política e Social) no estado. Antes que André Franco Montoro tomasse posse, eleito na primeira eleição direta para governador depois de duas décadas, todo o aparato da temida polícia 
política em São Paulo foi transferido para a Polícia Federal. Com isso, em vez do desmonte do aparelho repressivo, seguido por uma abertura de documentos e posterior encaminhamento jurídico, a única movimentação foi o reacomodamento de pessoas e instalações que, com outro nome, continuaram a mesma política de segurança.

Com destreza, tudo foi transformado para que nada mudasse. Maria Pia Guerra é clara quanto a isso:

O resultado duradouro foi a parca democratização, pois ao invés de a extinção do DEOPS ser acompanhada de medidas de transparência, foi na verdade um processo de encobrimento: junto com as competências legais, foram transferidos para a Polícia Federal também o diretor do DEOPS, Romeu Tuma, nomeado Superintendente da PF, sua equipe e todos os documentos e arquivos da delegacia política, só liberados para o Arquivo Público do Estado de São Paulo alguns anos depois (GUERRA, 2016: 85).

Ainda que a Carta Magna de 1988 tenha ficado conhecida como "Constituição cidadã" (provavelmente por conta do confronto com a situação legal durante a ditadura), os arranjos políticos do momento determinaram que ela "fosse marcada desde o início pelo signo da manutenção da autocracia burguesa" (MACIEL, 2014: 299). O jurista Alysson Mascaro nota que sua orientação foi decidida pelas mesmas estruturas que vinham do golpe, o que servia, mais do que tudo, para fazer com que os interesses das classes privilegiadas continuassem contemplados: "Não só a Constituinte de 1988 foi convocada pelas autoridades competentes a partir do ordenamento jurídico anterior, ditatorial, como também sua amplitude de atuação foi tolhida institucional e socialmente por partidos, interesses, disputas e meios de comunicação de massa fomentados pela ditadura" (MASCARO, 2018: 79)

Dessa forma, a segurança pública teria que contemplar agora a questão da violência urbana. Para isso, a Carta procurou garantir "a preservação do aparelho repressivo e de informações", (MASCARO, 2018, p. 79) embora estivesse mudando o alvo. A transformação vinha sendo ensaiada desde o fim dos anos 1970, com a distensão da ditadura, e tomou força até culminar na política para a área que a Constituição de 1988 acabou adotando. ${ }^{1}$

\footnotetext{
${ }^{1}$ No relatório final da Comissão Nacional da Verdade há inúmeras recomendações para a reforma das políticas de segurança pública. Entre elas, uma das mais ousadas é a desmilitarização das polícias militares estaduais. O texto é eloquente: “A atribuição de caráter militar às polícias militares estaduais, bem como
} 
Obviamente, no interior dessa nova política de segurança estava a garantia de que os crimes cometidos pelos agentes do Estado não seriam julgados. Afinal de contas, havia muito com o que se preocupar: a bandidagem que estava às portas da burguesia, por exemplo. É o momento em que programas de rádio e TV de forte apelo sensacionalista começam a aumentar sua audiência ainda mais. A criminalidade entrava para as manchetes para não sair mais...

Além disso, o aprimoramento do aparato repressivo no interior das instituições voltadas à segurança pública resolveria um problema prático: onde os funcionários que trabalhavam nos antigos centros de repressão seriam agora alojados? Elio Gaspari fez um pequeno levantamento:

No outro lado da equação, o Centro de Informações da Exército listou 49 colaboradores, procurando transferi-los para o serviço público federal. O delegado Romeu Tuma, diretor do DOPS, e o policial Laertes Calandra, identificado por vários presos como o Capitão Ubirajara do DOI, que requisitara a perícia do cadáver de Vladimir Herzog, transferiram-se para a Polícia Federal. O médico Harry Shibata, signatário da autópsia do jornalista, abrigou-se no Ministério do Trabalho² (GASPARI, 2016: 230).

Por fim, é importante ressaltar que esse tipo de manutenção institucional acaba causando a continuidade das violações cometidas durante a ditadura. O procurador Marlon Alberto Weichert enfatiza que na área da segurança esse caso é recorrente:

De fato, entidades que durante o período de conflito ou a ditadura foram estruturados e orientados para combater e reprimir dissidentes - restringindo e violando direitos humanos - certamente não abrirão mão de seus poderes ou

\footnotetext{
sua vinculação às Forças Armadas, emanou de legislação da ditadura militar, que restou inalterada na estruturação da atividade de segurança pública fixada na Constituição brasileira de 1988. Essa anomalia vem perdurando, fazendo com que não só não haja a unificação das forças de segurança estaduais, mas que parte delas ainda funcione a partir desses atributos militares, incompatíveis com o exercício da segurança pública no Estado democrático de direito, cujo foco deve ser o atendimento ao cidadão. Torna-se necessário, portanto, promover as mudanças constitucionais e legais que assegurem a desvinculação das 97218 conclusões e recomendações polícias militares estaduais das Forças Armadas e que acarretem a plena desmilitarização desses corpos policiais, com a perspectiva de sua unificação em cada estado" (COMISSÃO..., 2014: 971)

${ }^{2}$ Alguns militares foram bastante longevos em sua relação com as forças de segurança. Gaspari informa, por exemplo, que "o capitão José Brant Teixeira, um dos quadros mais ativos do CIE, passou para a reserva como coronel e reconheceu em seu depoimento ao Ministério Público Federal que esteve no Araguaia. Foi o Doutor Cesar no DOI do Rio. Dirigiu a Academia Nacional de Polícia de 1994 a 1995 e em 2001 era assessor especial da diretoria da ABIN" (GASPARI, 2016: 354).
} 
tampouco serão capazes de modificar sua cultura, apenas porque o regime entrou em colapso e foi substituído por outro. Há uma tendência inercial de manutenção do status quo que lhes era favorável e de rejeição a mudanças que afetem seu domínio. Assim, não é incomum que essas instituições (sobretudo as forças encarregadas da segurança pública) continuem a desrespeitar direitos dos cidadãos durante e após a transição, em um fenômeno que pode ser chamado de perpetuação da violação de direitos humanos (WEICHERT, 2018: 59).

Ainda na década de 1970, certa produção artística passou a tratar da violência urbana. Em 1975, a editora Civilização Brasileira lançou uma série de romances que pretendiam ficcionalizar acontecimentos e personagens famosos. Cru e muito violento, Lúcio Flávio, o passageiro da agonia, do escritor maranhense José Louzeiro, narra a trajetória do bandido homônimo, sem economizar em cenas de violência, tortura e corrupção policial. O filme baseado no livro, com roteiro e direção de Hector Babenco, vai no mesmo caminho, embora tenha sido obrigado pela censura a "não apresentar cenas ou situações que possam provocar incitamento contra as autoridades e seus agentes, proibidas pela legislação em vigor"3 (REIMAO, 2014: 19).

Rubem Fonseca deve ter sido o escritor mais bem-sucedido no que ficou conhecido como universo da violência urbana. Prolífico, além de ter praticamente inaugurado esse tipo de narrativa por aqui, influenciou obras de todo tipo: de Paulo Lins a Fernando Bonassi, passando por Patricia Mello e Marçal Aquino. Sempre que estupros, assaltos em profusão, a polícia tomando conta da cena junto com a bandidagem, algum tipo de herança de Fonseca vai aparecer.

A crítica não deixou de reconhecer seu trabalho desde a primeira hora, muitas vezes de forma bastante entusiasmada, como mostra essa passagem de Boris Schnaiderman:

Os contos de Rubem Fonseca, quando surgiram, causaram impacto com a brutalidade do submundo que expressavam. Por mais que numerosos autores tivessem tratado do tema, esses contos impressionavam. Não havia neles uma observação de fora para dentro, não tinham nada a ver com uma anotação

\footnotetext{
${ }^{3}$ Para uma análise mais profunda da questão, Cf. REIMAO, 2011.
} 
"etnográfica", mas, sobretudo, aquela brutalidade era algo cotidiano e corrente, a própria linguagem ficava marcada por ela.

De lá para cá, a vida brasileira, em seu conjunto, tornou-se mais brutal e implacável, fatos como os narrados ali passaram a fazer parte de nossa vivência diária e acabamos mais acostumados com eles. (SCHNAIDERMAN, 2004: 773)

Colocadas lado a lado, as afirmações de Pierucci e Schnaiderman se complementam. Fonseca, segundo o crítico literário, trouxe para o ambiente artístico a brutalidade que logo depois a vida social começaria a ressaltar como um de seus principais fantasmas, exatamente como o sociólogo descreve. Ao que parece, portanto, está aqui de fato uma das raízes que ajudou a solidificar os interesses da política de segurança nacional que estávamos apresentando.

A obra de Rubem Fonseca tem algumas fases, cujas diferenças, às vezes sutis, são denunciadoras do movimento que o autor de $A$ grande arte sempre realizou para se adequar à ideologia que mais interessava ao poder político dominante. Seu livro de estreia, Os prisioneiros, foi publicado em 1963 pela editora de um dos diretores do Instituto de Estudos e Pesquisas Sociais (IPES), uma agremiação cujo principal objetivo era ajudar nas condições ideológicas para o golpe militar de 1964. René Armand Dreifuss é claro ao afirmar que o Instituto agia

contra o Executivo, a esquerda e o trabalhismo. A elite orgânica, sobre a cobertura do Ipês, enfrentava o Executivo em constantes batalhas políticas, hostilizando-o e conseguindo reduzir o espaço político do governo para manobras, enquanto preparava um golpe estratégico militar dirigido ao centro de equilíbrio do regime. Tanto o Estado quanto a sociedade foram transformados em campo de batalha. As táticas e as técnicas políticas utilizadas na campanha para inviabilizar o regime de João Goulart e intervir militarmente assemelhavam-se muito às que se tornaram conhecidas após a experiência do Chile em 1973 pelo célebre eufemismo - "desestabilização"4 (DREIFUSS, 1981: 483).

\footnotetext{
${ }^{4}$ No ensaio "A grande arte de desaparecer" analiso com mais cuidado a participação de Rubem Fonseca no Ipês, sobretudo no que diz respeito à autoria dos roteiros dos famosos documentários do instituto. Cf. LÍSIAS, Ricardo. “A grande arte de desaparecer: Rubem Fonseca e os documentários do Ipês". ArtCultura, Uberlândia, v. 19, n. 35, p. 43-54, jul.-dez. 2017.
} 
Posteriormente, Fonseca afirmou que sua participação no IPES sempre esteve ligada ao desenvolvimento de ideias para aprimorar a democracia. O escritor afirma terse afastado do instituto quando o golpe militar ocorreu. ${ }^{5}$ Segundo Marcos Correia, porém, "há registros posteriores que indicam a permanência do escritor nos quadros e atividades da instituição" após 1964 (CORREA, 2009: 79). Aline Andrade Pereira nota "a aura de maldito que Rubem Fonseca fez questão de construir para si mesmo (e algumas críticas corroboram), que lutou contra as estruturas para ser publicado, por ter uma literatura muito diferente de seus contemporâneos" (PEREIRA, 2009: 136).

Fonseca publica três livros de contos em seguida, que podem ser lidos em conjunto, já que praticamente repetem tanto a estrutura formal quanto a tipologia das personagens e seus interesses, cenários e mesmo inclinação ideológica. É também de Aline Andrade Pereira um resumo preciso desse momento:

São personagens extremamente honestos, presos a estruturas corrompidas. Herois solitários que em geral passam por um episódio decisivo, que os leva a se corromper ou não. (...) Nesse tipo de personagem é possível ver as angústias de homens partidos entre dilemas morais, esmagados pelas contradições entre o caráter e a estrutura corrompida na qual se encontram. A violência desponta ainda timidamente e as diferenças sociais são tratadas ainda timidamente nesses contos. Ainda que não se restrinja a esses, o período mais comum em que esses personagens aparecem é até o terceiro livro do escritor, Lúcia MacCartney, de 1967. È desse período também a maioria dos contos que denomino orwellianos, por possuírem um claro aspecto de crítica a estados totalitários, alguns ironizando explicitamente a esquerda. (...) (PEREIRA, 2009: 24).

Entre 1975, ano da publicação dos contos de Feliz ano novo (que para alívio do autor seria proibido pela censura) e Vastas emoções e pensamentos imperfeitos, romance lançado em 1988, junto com a Constituição portanto, Fonseca publicou três romances e duas reuniões de contos. Todos apresentam um grande apuro formal, expresso sobretudo pela linguagem seca, a narrativa ágil e econômica, caracterizada pela descrição direta, diálogos curtos e um discurso indireto livre que no geral revela a complexidade de

\footnotetext{
${ }^{5}$ Em 1994, nosso autor afirmou o seguinte: "Eu afastei-me completamente do Ipês e nunca me aproximei do novo governo, nem daqueles que o sucederam. Não era, como homem de empresa, nem sou agora, como escritor, favorável à ruptura da ordem constitucional em nosso país através de revoluções ou golpes de estado, militares ou civis" (FONSECA, 1994: D1).
} 
algumas personagens. Da estreia para a maturidade, o autor evoluiu muito. É nesse conjunto de publicações que Fonseca aperfeiçoa a narrativa que o sociólogo Pierucci identificava entre os discursos conservadores que se assentaram no Brasil logo após a ditadura. Para efeito de análise, vou me concentrar em três pontos: a ridicularização do artista contemporâneo; a construção da figura do policial nesses livros e, consequentemente, a maneira com que a violência começa a ser tratada.

Não se trata de frase de efeito, e sim de percepção contábil: todos os artistas contemporâneos e intelectuais que aparecem na obra de Rubem Fonseca até 1988 (depois a situação não muda muito, mas meu objeto de estudo acaba aqui) são, para dizer o mínimo, figuras esdrúxulas. Nesse caso não há nenhum tipo de transição entre o início da obra e a maturidade. Pode-se dizer, sem medo de errar, que em toda a obra de Fonseca há duas constantes imutáveis: artistas e intelectuais somos sempre uns ridículos e as mulheres serão invariavelmente objetificadas.

Ainda no primeiro livro, Os prisioneiros, de 1963, o conto "Natureza podre ou Franz Potocki e o mundo" descreve um artista esquisito e perdido diante do próprio trabalho: "Ele mesmo não sabia ao certo o que queria dizer, mas o esforço para fazer cada quadro quase o matava; quantas vezes seu corpo tremera tanto que a espátula lhe caíra das mãos; ou sua vista escurecera e ele desmaiara para acordar horas depois no chão do estúdio" (FONSECA, 2004: 46). O texto serve só para caricaturizar a atividade artística, descrevendo um pintor depressivo que não fazia naturezas mortas, mas "podres". Os interessados nesse tipo de arte são, como o artista, bizarros:

Alguns de seus quadros foram vendidos por muitos milhões, como o "Getúlio `Podre”, leiloado na sede do Partido Trabalhista.

Sua série de "Orquídeas Podres" foi vendida inteiramente para a condessa Pepinelli e a condessa teve que dar oito recepções seguidas para que todos os seus amigos pudessem contemplar a última criação de Potocki. Entrevistada na casa de saúde, onde foi internada devido à fadiga resultante de recepções, a condessa, conhecida colecionadora de arte, declarou que Potocki era o maior artista vivo do mundo. (FONSECA, 2004, p. 44)

“***(Asteriscos)”, de Lucia McCartney, de 1969, satiriza a literatura dramatúrgica. Aqui, trata-se de uma colagem de uma entrevista do diretor de uma peça, 
matérias de jornal de divulgação, um relatório da censura e fragmentos de textos artísticos. De novo, tudo é caricatural e o diretor, tratado como uma figura bizarra:

\section{PROGRAMA}

$$
\text { JOSÉ HENRIQUE - A DIREÇÃO COMO CRIAÇÃO }
$$

"Minha biografia não interessa a ninguém", costuma dizer o jovem diretor de Endereços. José Henrique surgiu de repente no teatro brasileiro dirigindo Dias felizes! Colocou os dois personagens da peça inteiramente nus, a mulher manchada de fezes e o homem de sangue. "Hoje eu não perderia tempo com Beckett." Sua consagração, porém, foi com a adaptação de Juliette, de Sade. "A platéia de teatro é geralmente composta de estupradores latentes, homossexuais reprimidos e incestuosos sublimados, todos com complexo de culpa. É claro que a peça do divino Marquês teria que ter sobre eles um grande efeito catártico.” José Henrique não pensa mais em dirigir Sade. "Sade me interessou como uma experiência de consubstanciação do sexo da violência com a violência do sexo. Mas isso está superado. O orgasmo é um prato de batatas fritas." (FONSECA, 2004: 300).

A crítica é desequilibrada e agressiva: "Toda peça é feita de alegorias desse tipo, que podem fascinar a alguns críticos ignorantes (como a maioria dos críticos, aliás) mas não àqueles que sabem separar o bom do mau, independente da forma... ou do cheiro." (FONSECA, 2004: 304, grifo do autor) Sintomaticamente o mais lúcido é o censor:

Senhor Diretor, nossa conversa foi toda nesse diapasão. Confesso que não me lembro mais de tudo que foi dito, nem por quê. Um homem estranho, esse senhor José Henrique. Sua peça deverá ter as mesmas obscuridades. Não vejo, todavia, inconvenientes na sua apresentação, desde que limitada a maiores de vinte e um anos (FONSECA, 2004: 302).

Se na maturidade, em Feliz ano novo (de 1975), a visão de mundo evolui para as personagens ligadas à polícia e ao direito, para artistas e intelectuais tudo continua a mesma coisa. As descrições não são mais razoáveis sequer quando lidam com escritores. Aqui, mais um clichê: “"Por que você se tornou um escritor?' 'Gente como nós ou vira santo ou maluco, ou revolucionário ou bandido. Como não havia verdade no êxtase nem no poder, fiquei entre escritor e bandido"' (FONSECA, 2004: 461). 
Nos romances, a situação é a mesma. O narrador de Vastas emoções $e$ pensamentos imperfeitos, de 1988 (25 anos depois da estréia do escritor e no final do período que estamos lidando) é um cineasta em crise que consegue acabar em uma enorme confusão e arriscar a vida por conta de um manuscrito misterioso do escritor russo Isaak Bábel, de quem pretende adaptar o clássico Cavalaria vermelha. Como sempre, muita demonstração de erudição, mulheres à disposição do narrador, figuras bizarras (aqui por exemplo um cara que precisa cheirar um pó, não de cocaína mas de diamante, para viver...) e o intelectual tolo e descontrolado:

Antes que ele respondesse, acrescentei, mostrando o manuscrito na minha mão: "Está vendo isso?"

"Estou” disse Gurian. "Entra, entra."

"Isto aqui”, eu disse, entrando no apartamento, "é o manuscrito de Bábel que foi confiscado pela NKVD quando ele foi preso."

Contei tudo para Gurian> enquanto eu falava, Gurian, que tirara o manuscrito da minha mão, sacudia-o de maneira desesperada de encontro ao rosto, sapateava e chutava coisas que estavam no chão - havia sempre coisas no chão da sua casa, além dos livros - e exclamava palavras ininteligíveis.

Afinal entendi o que ele dizia: "Quebrei os meus óculos, não posso ler!".

"Não pode ler?!”, eu gritei. “Como não pode ler?!"

"Quebrei os meus óculos hoje de manhã. Pisei em cima deles."

"Como é que você foi pisar nos próprios óculos?! Isso é coisa de maluco."

Ficamos gritando algum tempo, exasperados, ele porque não podia ler imediatamente algo tão instigante e extraordinário como um texto inédito de Bábel e eu por depender de um velho maluco (FONSECA, 2004: 190).

As razões para que artistas e intelectuais serem no mais das vezes ridicularizados são no mínimo três: a) é mais ou menos dessa forma que o senso comum nos enxerga, como aliás se pode ver em iniciativas contemporâneas similares. A obra de Rubem Fonseca em alguns momentos resvala para uma espécie de glosa de alguns dos principais clichês da sociedade; b) a propósito, ele acaba selecionando-os a partir de razões ideológicas: o discurso conservador costuma repelir a arte moderna e contemporânea, 
acusando-a de ser uma agressão à tradição que, afinal de contas, Fonseca parece prezar; ${ }^{6}$ c) por fim, tratar-nos como figuras planas e patéticas irá causar um choque com outra categoria social muito presente e que será analisada a seguir. Como veremos, a obra em questão se aproveita muito do confronto de pares contraditórios.

Se artistas e intelectuais somos pintados invariavelmente como pessoas sem complexidade, meros simplórios que confirmam todos os clichês que o senso comum dispõe sobre nós, com os policiais e advogados (que no geral se confundem com investigadores), a situação é bem diferente. No longo conto que dá título à coletânea de 1969, A coleira do cão, e inaugura, portanto, a obra de Fonseca, um delegado aparece como um policial decidido e corajoso, pronto para liderar uma ação arriscada, e, ao mesmo tempo, sensível (é leitor de poesia) e com alguma consciência social. A contradição é tão grande que seus subordinados admitem não compreendê-lo:

"Flores artificiais sujas dentro de uma jarra de falso cristal. Móveis velhos estragados. Nem um livro sequer à vista. Roupas desbotadas. Um Sagrado Coração de Jesus na parede, também desbotado. O menino descalço. Houve um momento em que a tristeza das coisas foi maior do que a dor das pessoas."

"Puxa, doutor, até parece que o senhor nunca entrou em casa de pobre." "Já entrei sim. Mas meus olhos nem sempre sabem ver.

"Tem vezes que o senhor fica muito difícil de entender", disse Washington bocejando, cansado.

Vilela levantou a mão e tocou de leve, carinhosamente, no ombro de Washington. Depois sorriu, com a boca fechada, um sorriso curto, que se desfez lentamente. ${ }^{7}$ (FONSECA, 2004: 234).

Personagem icônica da segunda fase da obra de Rubem Fonseca, Mandrake aparece primeiro em um dos contos de Lucia McCartney ("O caso de F. A.") e depois, reaparece em coletâneas posteriores até se tornar uma das personagens principais de $A$ grande arte. Ele é culto, joga xadrez e ao mesmo tempo instrumentaliza o corpo de todas

\footnotetext{
${ }^{6}$ Michael Oakeshott, teórico do pensamento conservador, é bastante claro ao declarar o incômodo diante da inovação, uma das principais características da arte moderna (OAKESHOTT, 2017).

${ }^{7}$ Não vejo aqui nenhuma contradição com a afirmação, citada anteriormente, de que o policial nessa fase da obra de Fonseca, é uma figura honesta e que, depois ele desapareceria. Desde já, ainda assim, é possível ver a tensão que esse tipo de personalidade causa no interior da instituição.
} 
as mulheres que se aproximam dele. ${ }^{8}$ Em 1975, com a obra já madura, Fonseca lhe dedica um conto inteiro em $O$ cobrador, cujas preocupações são eloquentes: "Fui atrás. O carro fazia as curvas em alta velocidade, os pneus zunindo. Não era fácil segui-lo. É hoje que morro, pensei. Qual das minhas mulheres sofreria mais? Berta talvez deixasse de roer unhas" (FONSECA, 2004: 534). O conto se desenvolve com suspense e no final serve para que seu protagonista denuncie, com sutileza, embaraço e sem se colocar em um lugar de inocência, a ligação entre a polícia e a criminalidade, muito em evidência hoje por conta das milícias cariocas. A propósito, o texto imediatamente anterior do livro, "Encontro no Amazonas", parece existir apenas para nos deixar em dúvida sobre a identidade do narrador assassino: policial ou pistoleiro? A dificuldade que Fonseca tinha para analisar o trabalho artístico e intelectual não se repetia quando ele voltava os olhos para a polícia. Ainda que estivesse preocupado em trazer apara a sua ficção os interesses da classe governante, ele notou muito bem alguns dos principais problemas das polícias brasileiras.

Como se pode ver, Rubem Fonseca sabe criar personagens ricas, cheias de contradições e complexidades. Ele opta pelas figuras que irá tratar com cuidado estético e as que aparecerão de forma bastante patética, apenas através do mais constrangedor clichê. Uma dessas, que deixei para o final, aliás, é o bandido. Conforme vai se aproximando dos anos 1980, sua obra se foca cada vez mais na baixa marginalidade: o ladrão é tosco, cruel e sobretudo retirado de qualquer tipo de contexto.

Algumas vezes dá para perceber certo ódio social, com as classes baixas invadindo o espaço das altas, como naquele que deve ser seu conto mais conhecido e celebrado, "Feliz ano novo", de 1975. No dia do réveillon, um grupo de bandidos cruéis invade uma festa da classe alta em São Conrado e pratica uma série de atos selvagens, sem muita razão além da própria violência desmedida. Em "O cobrador", publicado no mesmo ano que a "lei de anistia" (1979), a violência gratuita que os contos descrevem vem sobretudo das classes baixas e acaba reduzida a uma manifestação desgovernada de ódio individual: "Quando satisfaço meu ódio sou possuído por uma sensação de vitória, de euforia que me dá vontade de dançar - dou pequenos uivos, grunhidos, sons inarticulados, mais próximos da música do que da poesia, e meus pés deslizam pelo chão, meu corpo se move num ritmo feito de gingas e saltos, como um selvagem ou um macaco. Quem quiser mandar

\footnotetext{
${ }^{8}$ Pode-se dizer que a objetificação da mulher é uma das características mais perenes da obra de Rubem Fonseca. Seu último livro, Carne crua, de 2018, tem causado constrangimento já a partir da capa, que mostra uma mulher sendo vendida como se fosse carne de supermercado (CINTRA, 2019: 5).
} 
em mim pode querer, mas vai morrer." (FONSECA, 2004: 500). A objetificação da mulher é tão forte que mesmo em meio a um estupro, descrito de forma barata e cheia de lugares comuns, ela tem um orgasmo:

Tira a roupa.

Não vou tirar a roupa, ela disse, a cabeça erguida.

Estão me devendo xarope, meia, cinema, filé mignon e buceta, anda logo. Dei-lhe um murro na cabeça. Ela caiu na cama, uma marca vermelha na cara. Não tiro. Arranquei a camisola, a calcinha. Ela estava sem sutiã. Abrilhe as pernas. Coloquei os meus joelhos sobre as suas coxas. Ela tinha uma pentelheira basta e negra. Ficou quieta, com os olhos fechados. Entrar naquela floresta escura não foi fácil, a buceta era apertada e seca. Curvei-me, abri a vagina e cuspi lá dentro, grossas cusparadas. Mesmo assim não foi fácil, sentia o meu pau esfolando. Deu um gemido quando enfiei o cacete com toda a força até o fim. Enquanto enfiava e tirava o pau eu lambia os peitos dela, a orelha, o pescoço, passava o dedo de leve no seu cu, alisava sua bunda. Meu pau começou a ficar lubrificado pelos sucos de sua vagina, agora morna e viscosa.

Como já não tinha medo de mim, ou porque tinha medo de mim, gozou primeiro do que eu. Com o resto da porra que saía do meu pau fiz um círculo em volta do umbigo dela.

Vê se não abre mais a porta pro bombeiro, eu disse, antes de ir embora. (FONSECA, 2004: 498).

A polícia aparece nos dois romances que Rubem Fonseca publica no período. $\mathrm{O}$ enredo no mais das vezes se dá longe de qualquer procedimento oficial e organizado. A instituição parece perdida, em meio a procedimentos confusos, ilegais ou muitas vezes patéticos. O resultado sempre é o acirramento da violência e, de forma nenhuma, parece haver qualquer interesse em uma solução para o descompasso entre as instituições desfuncionais de segurança e a necessidade de que seu trabalho seja feito com alguma ordem razoável.

Em A grande arte, de 1983, por exemplo, o narrador se envolve com uma mulher, achando que fosse uma prostituta, mas que na verdade se tratava de uma agente da polícia federal. Obviamente, seu engano custará caro para a vida dos outros. A grande arte pode ser descrito como uma ode à violência gratuita ou, mais ainda, ao ódio. Espécie de jogo de gato e rato entre Mandrake, que já apresentamos, e um criminoso boliviano, Camilo 
Fuentes, o livro narra o assassinato, sempre com requintes de crueldade, de prostitutas, que sempre acabam com o rosto marcado por uma letra. A busca por uma fita de videocassete (àquela época o meio audiovisual mais comprometedor) é pretexto para um desfile de mágoas e raiva desmedida.

Aline Pereira nota que para Mandrake, o ódio aparece "como uma característica quase natural do ser humano" (FONSECA, 2004: 175). Dessa forma, Fonseca constrói um policial que acredita no homem como dotado intrinsecamente de raiva e, ao mesmo tempo, constrói a bandidagem dessa forma. É como se ele quisesse mostrar que polícia e bandido se complementam e um serve para ilustrar o que o outro pensa.

O enredo do romance parece confirmar essa hipótese. No final, nada será esclarecido e toda a violência - que, como vimos, não é pequena - acaba de fato sem nenhuma razão. Se houver uma ideia nesse romance, é a de que o ser humano de fato tem uma natureza bastante problemática. O passo aqui é ainda maior: se o bandido serve para ilustrar com precisão o que pensa o policial, o livro existe para que uma narrativa maior abrigue essa junção e demonstre que ela funciona bem. A conclusão pode ser inusitada, mas estamos diante de uma espécie de romance de tese.

Buffo \& Spallanzani, de 1986, é menos violento e sintomaticamente, traz de volta para o centro da narrativa um policial, Guedes, que vai tentar elucidar um assassinato ocorrido no interior da classe alta. Sem se dobrar à corrupção e muito esforçado no ofício, o investigador encontra as dificuldades de sempre: uma estrutura engessada, que existe para fazer com que as coisas não sejam esclarecidas e abriga pessoas que justamente trabalham para que tudo continue como está. A corrupção da polícia termina recaindo sobre ele, que fica praticamente emparedado. A investigação, obviamente, não funciona direito.

De forma alguma Rubem Fonseca pinta a instituição policial como livre de defeitos. Ao contrário, o funcionamento é sempre precário e no mais das vezes ineficaz. Aqui, é preciso reconhecer que ainda nos anos 1970 ele nota a corrupção e o conluio entre Estado e marginalidade, cuja explosão só se daria décadas depois.

O que a obra de Fonseca faz, a despeito de sua enorme relevância, é colocar em primeiro plano, entre os vários conflitos da crescente sociedade urbana, a violência. E aqui, como vimos, a dimensão preferida é a da ausência de contextualização, preterida pela crueza das imagens e o reforço dos clichês que assombravam a população. A ausência de razão clara para os crimes e a preferência pela explicitação de uma dicotomia que tornaria, como queriam os responsáveis pela nova política de segurança pública, 
vítimas de um lado e culpados de outro. No meio deles uma enorme população que precisaria ser protegida, conforme Pierucci notou.

O aspecto conservador da obra de Rubem Fonseca pode ser também observado em outra questão formal: muitas de suas narrativas, para continuar usando o termo de Pierucci, estruturam-se a partir da oposição de pares contrários, cuja tensão é no mais das vezes o motor que faz o texto andar.

Ainda do livro inicial, "Henri" opõe iniciativa privada a estatismo para compor a personalidade de um psicopata. O tempo inteiro ele se debate sobre esse tipo de oposição, o que perturba seu equilíbrio já bem pouco estável. O conto seguinte, "Curriculum vitae" coloca outra oposição, a do dinheiro versus diversão. Nos contos em que a violência é o assunto central a polarização torna-se ainda mais forte. De fato ${ }_{2}$ o que existe é um lado contra o outro:

Por um segundo o GG olhou o rosto de Pan. Subitamente o GG enfiou a mão dentro do paletó. Mas o Exterminador foi mais rápido. Sua 54 Superchata detonou abrindo um buraco em cima do olho direito do GG, que caiu de bruços sobre o braço que segurava a própria arma ainda dentro do paletó.

O Exterminador curvou-se sobre o corpo caído. Apoiou o cano da arma na base do crânio do GG e detonou uma segunda vez.

É preciso tomar cuidado, a medicina de hoje está muito adiantada, pensou o Exterminador enquanto pisava nos miolos do GG espalhados pelo chão (FONSECA, 2004: 269).

Esse é o final do conto "O quarto selo (fragmento)" de Lucia McCartney, de 1969. Vale lembrar que os apologistas da violência cometida pelo regime militar sempre se utilizaram da assim chamada "Teoria dos dois demônios". Renan Quinalha explica com clareza do que se trata: "sua característica central é utilizar a ação armada de grupos opositores como antecedente e justificativa para a repressão organizada do Estado" (QUINALHA, 2013: 190). Assim, para além da simplicidade da discussão, por mera oposição de contrários tenta-se justificar a opressão, os crimes contra a humanidade e todos os outros excessos cometidos pelo Estado, que estaria apenas respondendo às agressões de grupos organizados. ${ }^{9}$

\footnotetext{
${ }^{9}$ Para uma discussão sobre a consequência da "Teoria dos dois demônios" em textos historiográficos mais recentes, cf. BAUER 2016.
} 
Como se pode ver, não foi por ter tido um livro pateticamente censurado que Rubem Fonseca deixou de se alinhar com todas as fases do regime militar brasileiro, inclusive a transição, cuja principal marca foi deixar para o período democrático a herança de uma política de segurança violenta, segregadora e impune. Por fim, em um texto de 1979, nosso autor chama a ditadura de revolução:

Medeiros disse que a situação não era grave, mas também não era tranqüila. Medeiros só pensava em política, tinha sido coisa-e-loisa no início da revolução e apesar do seu escritório ser o maior da cidade ele não se libertava da nostalgia do poder. Perguntei se ele conhecia um tal de Cavalcante Meier (FONSECA, 2004: 524).

\section{Fontes}

FONSECA, Rubem (1994). Anotações de uma pequena história. Folha de S. Paulo, 27 mar.

FONSECA, Rubem (2004). Contos reunidos. São Paulo: Companhia das Letras.

\section{Referências Bibliográficas}

BAUER, Caroline Silveira e Fernando Felizardo Nicolazzi (2016). O historiador e o falsário Usos públicos do passado e alguns marcos da cultura histórica contemporânea. Varia História, Belo Horizonte, vol. 32, n. 60, p. 807-835, set/dez.

CINTRA, Jaíne (2019). "Gênero, imagem e hierarquia na capa de Carne crua de Rubem Fonseca". Suplemento Pernambuco. n. 156, fev.

COMISSÃO Nacional da Verdade. Relatório / Comissão Nacional da Verdade (2014). Recurso eletrônico. - Brasília: CNV.

CORRÊA, Marcos (2009). Cenas de um casamento perfeito: a ação burocrático-política do escritor José Rubem Fonseca no Ipes entre os anos de 1962/1964. Terceira margem, n. 21, ago.-dez. 2009, pp. 65-78.

DREIFUSS, René Armand (1981). 1964: a conquista do Estado - ação política, poder e golpe de classe. Petrópolis: Vozes.

GASPARI, Elio (2016). A ditadura acabada. Rio de Janeiro: Intrínseca.

GUERRA, Maria Pia (2016). Polícia e ditadura: a arquitetura institucional da segurança pública de 1946 a 1988. Brasília: Ministério da Justiça e Cidadania.

LÍSIAS, Ricardo. “A grande arte de desaparecer: Rubem Fonseca e os documentários do Ipês". ArtCultura, Uberlândia, v. 19, n. 35, p. 43-54, jul.-dez. 2017

MACIEL, Davis (2014). A aliança democrática e a transição política no Brasil. In: PINHEIRO, Milton (Org.). Ditadura: o que resta da transição. São Paulo: Boitempo Editoral. 
MASCARO, Alysson (2018). Crise e golpe. São Paulo: Boitempo Editorial.

OAKSHOTT, Michel (2017). Conservadorismo. Belo Horizonte: Ayné.

PEREIRA, Aline Andrade. O verdadeiro Mandrake: Rubem Fonseca e sua onipresença invisível (1962-1989) Tese (Doutorado em História). Universidade Federal Fluminense. 2009.

PIERUCCI, António Flávio (1987). As bases da nova direita. Novos Estudos CEBRAP, n. 19 , dez..

QUINALHA, Renan (2013). Com quantos lados se faz uma verdade? Notas sobre a Comissão Nacional da Verdade e a 'teoria dos dois demônios'. Revista Jurídica da Presidência Brasília, v. 15 n. 105, fev.-maio, pp. 181-204.

REIMAO, Sandra (2014). Lúcio Flávio. Sobre a censura ao livro e à adaptação cinematográfica. Revista Eletrônica Literatura e Autoritarismo, n. 23, jan.-jun., pp.11-21

SCHNAIDERMAN, Boris (2004). Posfácio. In: FONSECA, Rubem. Contos reunidos. São Paulo: Companhia das Letras.

WEICHERT, Alberto (2018). Apontamentos sobre justiça de transição. In: BRASIL. Ministério Público Federal. Câmara de Coordenação e Revisão, 2. Justiça de transição, direito à memória e à verdade : boas práticas / $2^{\mathrm{a}}$ Câmara de Coordenação e Revisão, Criminal ; $6^{a}$ Câmara de Coordenação e Revisão, Populações Indígenas e Comunidades Tradicionais ; Procuradoria Federal dos Direitos do Cidadão. Brasília : MPF.

Artigo recebido em 08 de março de 2019.

Aprovado em 15 de maio de 2019.

DOI: 10.12957/intellectus.2019.39520 